\title{
Biodecolorization of Remazol Brilliant Blue-R dye by Tropical White-Rot Fungi and Their Enzymes in The Presence of Guaiacol
}

\author{
Sita Heris Anita ${ }^{*}$, Fitria Ningsih ${ }^{2}$, Dede Heri Yuli Yanto ${ }^{1 *}$ \\ ${ }^{1}$ Research Center for Biomaterials, Indonesian Institute of Sciences (LIPI), West Java, Indonesia \\ ${ }^{2}$ Department of Biology, Universitas Indonesia, West Java, Indonesia
}

\begin{abstract}
Corresponding Author:
Sita Heris Anita

sita.heris@biomaterial.lipi.go.id

Dede Heri Yuli Yanto

dede@biomaterial.lipi.go.id

Received: February 2021

Accepted: June 2021

Published: September 2021

CSita Heris Anita et al. This is an open-access article distributed under the terms of the Creative Commons Attribution License, which permits unrestricted use, distribution, and reproduction in any medium, provided the original author and source are credited.
\end{abstract}

\begin{abstract}
The ability of the tropical white-rot fungi and their enzyme to decolorize synthetic dyes was investigated. Production of lignin-modifying enzymes (LMEs) from the three new isolated fungi, namely Trametes hirsuta D7, Ceriporia sp. BIOM 3, and Cymatoderma dendriticum WM01 were observed for 9 days incubation under static condition. The results showed that the LMEs production enhanced in the present of guaiacol. T. hirsuta D7 produced only laccase (Lac), with the highest activity was $22.6 \mathrm{U} / \mathrm{L}$ on the 5 th-day of the cultivation. At the same time, Ceriporia sp. BIOM 3 and C. dendriticum WM01 secreted both laccases (Lac) with the activities $0.2 \mathrm{U} / \mathrm{L}$ and $1.0 \mathrm{U} / \mathrm{L}$, respectively, and manganese peroxidase $(\mathrm{MnP})$ with the activities $0.1 \mathrm{U} / \mathrm{L}$ and 1.0 U/L, respectively. Among the fungi, T. hirsuta D7 efficiently degraded 65\% Remazol Brilliant Blue-R (RBBR) dye within $72 \mathrm{~h}$ using the only laccase. This study shows that laccase may have a major role in synthetic dyes' decolorization process, followed by MnP and LiP.
\end{abstract}

Keywords: decolorization, dye removal, lignin modifying enzyme, tropical fungi, synthetic dyes

\section{Introduction}

The production of numerous chemicals, including dyes, increased along with intensive industrialization. Synthetic dyes are mostly used in the coloring process of paper, plastics, leather, cosmetics, and textiles industries. During processing in industries, $10-15 \%$ of dyestuff is released into waterways as effluents ${ }^{[1],[2]}$. The presence of dyes in the aquatic ecosystem reduces the penetration of sunlight, declining photosynthetic activity, and decreasing the solubility of gases that causes toxic effects on aquatic organisms. Moreover, dye-containing effluents are toxic, mutagenic, carcinogenic, and highly resistant to degradation by native microorganisms ${ }^{[3]}$. Therefore, the search for appropriate technologies for removing dyes from industrial wastewater is an important priority[4].

Treatment of dye wastewater can occur physically, chemically, and biologically. The physical treatment removes the dye by the adsorption process, in chemical treatment, chromophores of dyes are modified by chemical reaction, while biological treatment occurs through adsorption and enzymatic degradation. However, biological treatment using microbial provide an alternative technology to the existing physical and chemical process. The advantages of biological technology are the low cost, 
complete mineralization process, and environmentally friendly[5],[6].

Many researchers have extensively reported biodegradation of the dye by white-rot fungi (WRF). Molares-Alvarez[7] reported the malachite green and crystal violet dye decolorization by WRF Pleurotus ostreatus. Falah et al[8] also reported that Leiotrametes flavida was a potential white-rot fungus for the decolorization of anthraquinone dyes. Several other WRF such as Hirschioporus larincinus, Inonotus hispidus, Phlebia tremellosa, and Coriolus versicolor can be used to decolorize dye effluent ${ }^{[9]}$. White rot fungi have commonly known as the most efficient microorganisms in breaking down synthetic dyes due to their ability to produce one or more extracellular lignin-modifying enzymes (LMEs) such as laccase, manganese peroxidase $(\mathrm{MnP})$, and lignin peroxidase $(\mathrm{LiP})$. Their lack of substrate specificity makes them potentially degrading a wide range of synthetic dyes such as anthraquinone, mono-azo, and diazo[10],[11].

Indonesia, as a tropical country, has a high biodiversity of microorganisms, including fungi. A total of 200,000 species of 1.5 million species of fungi are estimated to be found in Indonesia ${ }^{[12]}$. Research on bioremediation or the use of microorganism or their enzymes for biodegradation of contaminated environments into the original condition is still ongoing. Many investigators have isolated fungi from the environment for the biodegradation of textile dyes. Phanerochaete chrysosporium, Trametes hirsuta[13], Lentinus polychrous ${ }^{[14]}$ Trametes versicolor, Pestalotiopsis sp. ${ }^{[15]}$, and many others have been used in the decolorization studies. Researchers should utilize the biodiversity of fungi in Indonesia's forests by exploring, collecting, and screening potential fungus for different industrial use, especially for decolorizing textile wastewater. This paper presents the potential of the tropical fungi isolated from several locations in Indonesia for decolorization of anthraquinone synthetic dye. The LMEs production by the fungi is also investigated during the decolorization process.

\section{Experimental}

\section{Materials}

Microorganisms used in this study were fungi Trametes hirsuta D7, Ceriporia sp. BIOM 3, and Cymatoderma dendriticum WM 01. T. hirsuta D7 was isolated from peat swap forest Bengkalis, Riau. Ceriporia sp. BIOM 3 was isolated from Cibinong Science Center area, Cibinong, Bogor, and Cymatoderma dendriticum WM01 was isolated from Laiwangi-Wanggameti Forest, Sumba. Remazol Brilliant Blue R (RBBR) dye, guaiacol, and 2,2-azino-bis-[3-ethyl benzothiazoline- 6-sulphonic acid] (ABTS) were obtained from Sigma-Aldrich (USA). Malt extract and peptone were obtained from HiMedia Chemicals (Mumbai, India), while other chemicals were procured from Merck (Germany).

\section{Instruments}

The instrument used in this study were centrifuge (Wise Spin CF-10), hot-plate, digital analytical balance (Mettler Toledo, Switzerland), UV-Vis spectrophotometer (UV-1800 Shimadzu, Japan) for measuring the absorbance of dyes and laboratory glassware such as Erlenmeyer flask, volumetric flask, test tube, and petri dish.

\section{Methods}

\section{Fungal pre-culture and determination of fungal growth and decolorization rate}

Fungal isolates were pre-cultured on malt extract agar (MEA) individually and incubated at $27 \pm 3{ }^{\circ} \mathrm{C}$ for 7 days. One plug of pre-cultured isolate (diameters of $8 \mathrm{~mm}$ ) was placed onto a double-layer agar medium containing RBBR dye and incubated at $27 \pm 3{ }^{\circ} \mathrm{C}$ within $7-9$ days. The composition of the double layer agar medium (per liter) was according to Anita et al[16]. The diameter of fungal growth and the clear zone's formation indicated that the decolorization rate was measured every day for 7-9 days. The growth and the decolorization rate data were expressed in $\mathrm{cm} /$ day. 


\section{Enzyme production}

Fungal isolates were grown individually in 20 $\mathrm{mL}$ of malt extract-glucose-peptone (MGP) medium in a $100-\mathrm{mL}$ Erlenmeyer flask. The MGP medium (per liter of distilled water, $\mathrm{pH}$ 4.5) consists of malt extract $20 \mathrm{~g}$, glucose $20 \mathrm{~g}$, and peptone $1 \mathrm{~g}$. The addition of guaiacol was investigated to determine the effect of inducer on enzymatic activity. Twenty milliliters of sterilized MGP were inoculated with three plugs of fungal pre-culture and incubated at the static condition at room temperature $\left(27 \pm 3{ }^{\circ} \mathrm{C}\right)$ for 9 days. Enzyme activity was observed for 1, 3, 5, 7, and 9 days. All the experiments were conducted in two replications.

\section{Dye decolorization}

One milliliter of RBBR dye stock solution (2000 $\mathrm{mg} / \mathrm{L}$ ) was added to the fungal culture at the optimum incubation time for enzyme production to a final concentration of $100 \mathrm{mg} / \mathrm{L}$. Uninoculated Erlenmeyer flasks served as a control. The decolorization efficiency was observed for 24,48 , and $72 \mathrm{~h}$ after the reaction. All the experiments were conducted in two replications.

\section{Decolorization assay}

The supernatant from the filtration of the fungal culture was used for decolorization assay using a UV-vis spectrophotometer (UV-1800 Shimadzu, Japan). Dye decolorization was determined by measuring the absorbance change of RBBR dye at $592.5 \mathrm{~nm}$. Decolorization efficiency $(\mathrm{R}, \%)$ was calculated according to the following formula ${ }^{[15]}$ :

$R=(1-($ Absorbance observed $) /($ Absorbance initial $)) \times 100$

\section{Enzyme assay}

Laccase activity was measured by monitoring the oxidation of 2,2-azino-bis-[3-ethyl benzothiazoline- 6-sulphonic acid] (ABTS) at 420 $\mathrm{nm}$. One unit of laccase activity was defined as the amount of enzyme necessary to oxidase one $\mu \mathrm{mol}$ of the substrate in $1 \mathrm{~min}$. The reaction mixture for laccase assay contained $100 \mu \mathrm{L}$ of culture filtrate, $400 \mu \mathrm{L}$ of $0.1 \mathrm{M}$ acetate buffer $\mathrm{pH}$ 4.5 , and $500 \mu \mathrm{L}$ of $2 \mathrm{mM}$ ABTS[17].

LiP activity was determined by the oxidation of veratrylic alcohol at $310 \mathrm{~nm}$. One unit of $\mathrm{LiP}$ was defined as the amount of enzyme that oxidized one $\mu \mathrm{mol}$ of veratrylic alcohol per minute. The reaction mixture for the $\mathrm{LiP}$ assay was composed of $1 \mathrm{~mL}$ culture filtrate, $0.3 \mathrm{~mL}$ of $2 \mathrm{mM} \mathrm{H}_{2} \mathrm{O}_{2}$, and $2 \mathrm{~mL} \mathrm{LiP}$ buffer ${ }^{[18]}$.

The formation of $\mathrm{Mn}^{3+}$ determined manganese peroxidase activity in sodium malonate buffer ( $\mathrm{pH} 4.5$ ) in the presence of $\mathrm{H}_{2} \mathrm{O}_{2}$ at $470 \mathrm{~nm}$. One unit of $\mathrm{MnP}$ was defined as the amount of enzyme required to form $1 \mu \mathrm{mol}$ of $\mathrm{Mn}^{3+}$ in 1 min. The reaction mixture for $\mathrm{MnP}$ assay consisted of $100 \mu \mathrm{L}$ culture filtrate, $845 \mu \mathrm{L}$ of 50 $\mathrm{mM}$ malonic buffer ( $\mathrm{pH} 4.5$ ), $12.5 \mu \mathrm{L}$ of $20 \mathrm{mM}$ 2,6-dimethoxyphenol (DMP), $12.5 \mu \mathrm{L}$ of $20 \mathrm{mM}$ $\mathrm{MnSO}_{4}$, and $30 \mu \mathrm{L}$ of $2 \mathrm{mM} \mathrm{H}_{2} \mathrm{O}_{2}{ }^{[16]}$.

The following formula was used for calculating the enzyme activity (U/L):

Enzyme activity $\left(\frac{U}{L}\right)=\frac{(\text { Abs.final }- \text { Abs.initial }) \times \text { mixture }(L) \times 10^{3}}{(\varepsilon \times \text { V.enzyme }(L) \times t)}$

Where: 103: correction factor $(\mu \mathrm{mol} / \mathrm{mol}), \varepsilon$ for laccase, $\mathrm{LiP}$, and $\mathrm{MnP}$ were 36,000; 9300; and 49,600 , respectively.

\section{Results and Discussion}

Fungal isolates were analyzed for their growth and decolorization rate on solid agar medium (Table 1). The results showed that decolorization activity by $T$. hirsuta D7 occurs along with the growth process. It can be seen from the value of both growth and decolorization rate, which were identical: $1.54 \mathrm{~cm} /$ day-meanwhile, two other fungal isolates, Ceriporia sp. BIOM3 and C. dendriticum WM01 had a higher growth rate than the decolorization rate. 
However, three isolates showed a positive correlation between the growth rate and decolorization ability. The decolorization ability of each fungus depends on the production of extracellular enzymes, especially ligninmodifying enzymes (LMEs). LMEs system comprises the three enzymes, namely two glycosylated heme-containing peroxidases: lignin peroxidase (LiP, E.C.1.11.1.14) and manganese peroxidase (MnP, E.C. 1.11.1.13), and a copper-containing phenoloxidase: laccase (E.C. 1.10.3.2[19],[20]. Each species of white-rot fungi (WRF) variously secretes one or more of the three extracellular LMEs that are essential for lignin degradation as well as dye decolorization [2][22], and the production depends on the fungal species, culture types, and the conditions of cultivation ${ }^{[22]}$.

Variation in the yield of LMEs production making, not all the WRF species can appropriate for mycoremediation. In this study, we examined the LMEs production of each fungal isolate. The effect of guaiacol as an inducer on
LMEs production was also evaluated. LMEs, especially laccase, were constitutive or inducible enzymes and were produced during secondary metabolism. Its production depends on the nutrient such as carbon, nitrogen, and inducer in the medium ${ }^{[23]}$.

The LMEs production by three fungal isolates is shown in Figure 1-3. The LMEs were produced higher in the presence of guaiacol than that of the absence. Other research also reported that guaiacol enhanced the laccase production by Pleurotus ostreatus [24]. The highest laccase activity observed in T. hirsuta D7 was $22.6 \mathrm{U} / \mathrm{L}$ at five days of cultivation. However, manganese peroxidase $(\mathrm{MnP})$ and lignin peroxidase $(\mathrm{LiP})$ were only detected on the first-day cultivation, and the activities were not detected until the end of cultivation (9 days) (Figure 1). By contrast, Ceriporia sp. BIOM 3 and C. dendriticum WM01 secreted both laccase and MnP. Ceriporia sp. BIOM 3 produced MnP with lower activity than laccase activity, and no LiP activity was detected (Figure 2).

Table 1. The growth and decolorization rate of fungal isolates

\begin{tabular}{lcc}
\hline \multicolumn{1}{c}{ Isolate } & Growth Rate (cm/day) & Decolorization Rate (cm/day) \\
\hline Trametes hirsuta D7 & $1.54 \pm 0.13$ & $1.54 \pm 0.22$ \\
Ceriporia sp. BIOM 3 & $2.14 \pm 0.04$ & $1.45 \pm 0.18$ \\
Cymatoderma dendriticum WM01 & $1.34 \pm 0.04$ & $0.55 \pm 0.05$ \\
\hline
\end{tabular}
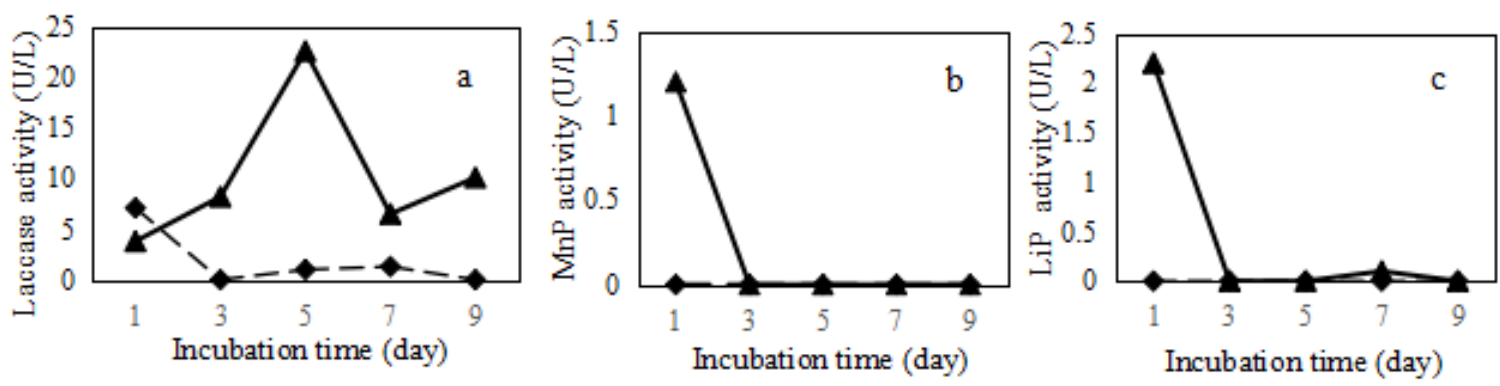

Figure 1. Laccase (a), MnP (b), LiP (c) activities produced by T. hirsuta D7 in medium with (A) and without $($ guaiacol. 

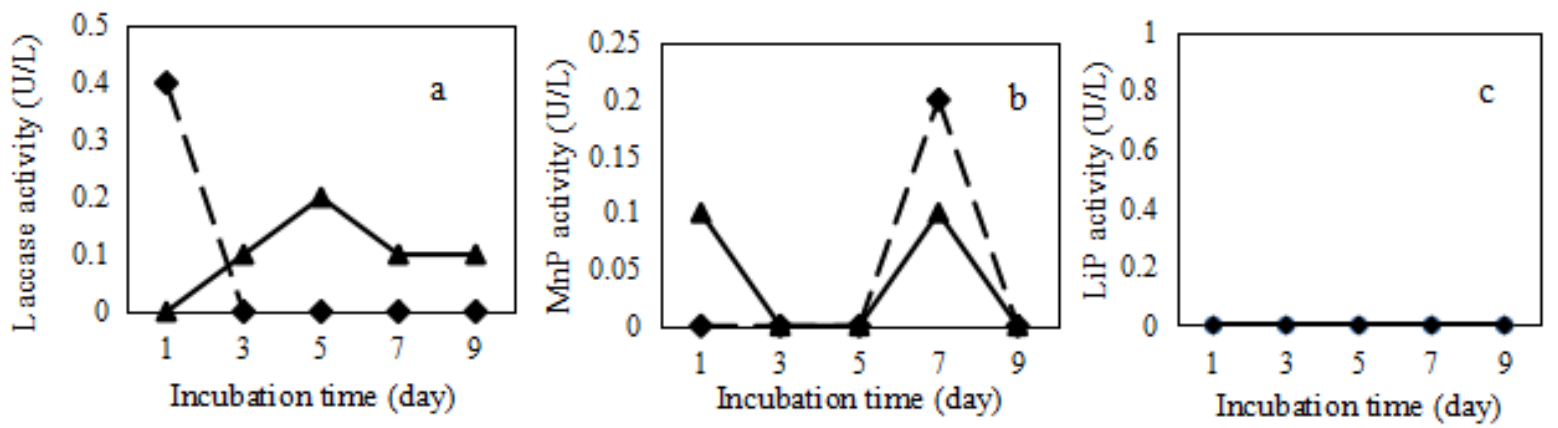

Figure 2. Laccase (a), MnP (b), LiP (c) activities produced by Ceriporia sp. BIOM 3 in medium with ( $\mathbf{\Delta})$ and without guaiacol.
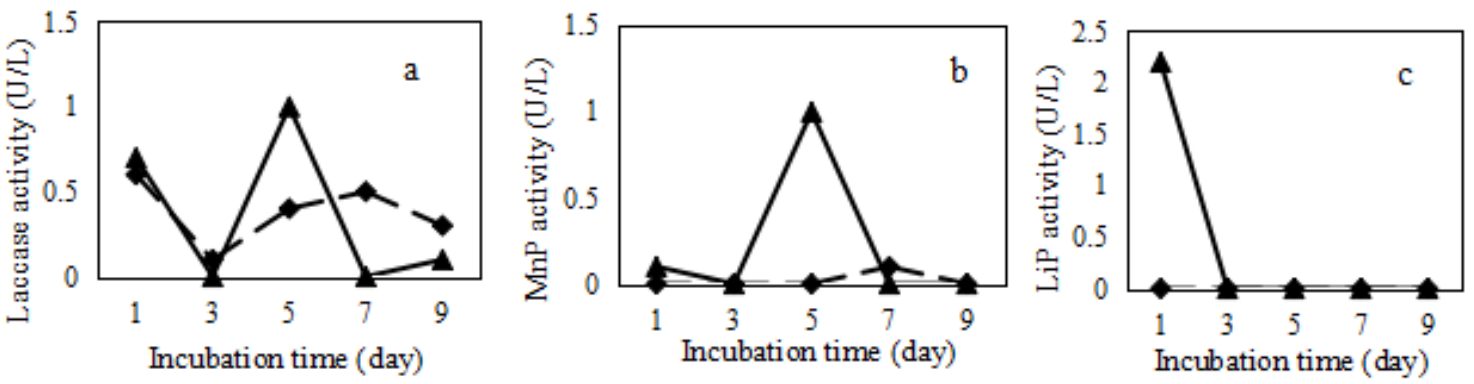

Figure 3. Laccase (a), MnP (b), LiP (c) activities produced by $C$. dendriticum WM01 in medium with $(\mathbf{\Delta})$ and without $(\mathbf{)})$ guaiacol.

The MnP activity produced by $C$. dendriticum WM01 was proportional to laccase activity and optimum at five days of cultivation. LiP activity by $C$. dendriticum WM01 was only detected on the first-day cultivation (Figure 3).

WRF can be classified based on the type LMEs produced by the fungi. In our study, the three isolates produced high laccase and $\mathrm{MnP}$, but poorly LiP was detected. Dao et al. ${ }^{[25]}$ also reported that their isolates, Cerenna sp. isolate Lyc23 and Rigidoporus vinctus NZD-mf190, did not produce LiP in the extracellular medium. However, it is uncertain whether the fungal collection can produce LiP enzyme because, in this study, the fungi were only cultivated in a liquid medium. Another study reported that WRF secreted the LiP enzyme at a solid-state fermentation system or in a carbon-limited medium[25].
The dye decolorization ability of LMEs produced by three fungal isolates was tested against the anthraquinone synthetic dye, RBBR (Figure 4). The study showed that $T$. hirsuta D7 decolorized $65 \%$ of $100 \mathrm{mg} / \mathrm{L}$ RBBR within $72 \mathrm{~h}$. While Ceriporia sp. BIOM 3 and C. dendriticum WM01 exhibited 52\% and 50\% decolorization, respectively. Although the two enzymes: laccase and $\mathrm{MnP}$ were mainly detected in the liquid medium during the decolorization, the laccase seems to have a major role in the decolorization process of RBBR dye. It can be supposed from the highest decolorization in the culture of $T$. hirsuta D7 due to the noteworthy production of laccase alone compared to Ceriporia sp. BIOM 3 and $C$. dendriticum WM01. Generally, laccase is the main enzyme for dye decolorization, followed by $\mathrm{MnP}$ and $\mathrm{LiP}[26]$. 


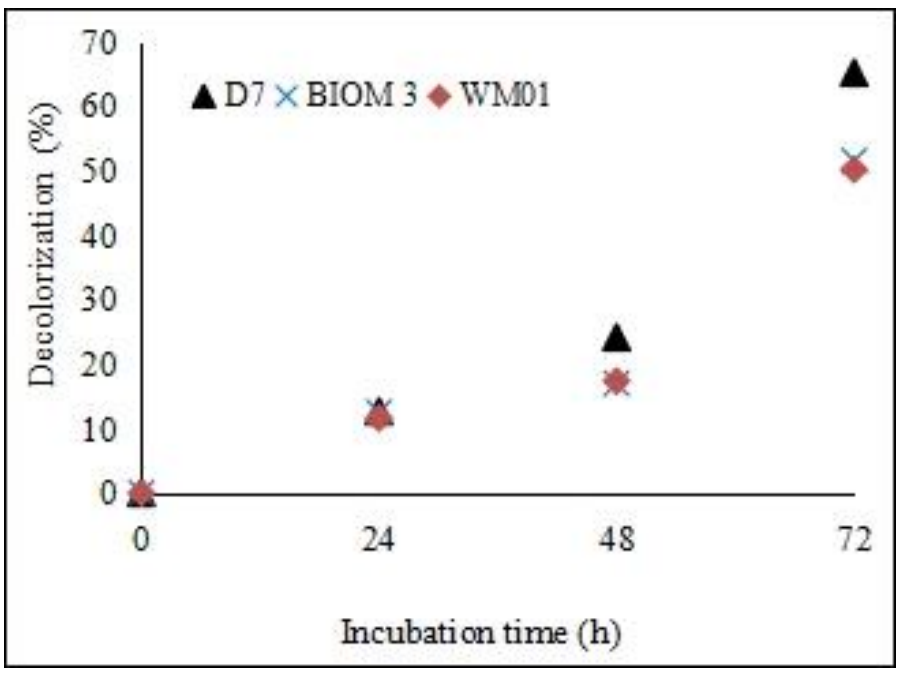

Figure 4. Decolorization efficiency of RBBR by the three fungal isolates.

\section{Conclusions}

Tropical fungal isolates, especially T. hirsuta D7, showed a positive correlation between the growth rate and decolorization ability, which was $1.54 \mathrm{~cm} /$ day. The addition of guaiacol as an inducer enhanced the production of LMEs. Remarkable decolorization of RBBR dye as much as $65 \%$ was found in the culture of $T$. hirsuta D7, which produced the highest laccase activity $(22.6 \mathrm{U} / \mathrm{L})$, which indicated the role of laccase in the decolorization of RBBR dye. The study suggests that the LMEs, particularly laccase produced by tropical fungal isolates, can be used for bioremediation of synthetic dyes wastewater from textile industries.

\section{Acknowledgments}

The authors are thankful to the Integrated Laboratory of Bioproducts (ILaB) at the Indonesian Institute of Science (LIPI) for the facilities, the scientific and technical assistance. This research was supported by LIPI through Priority Program on Material, Energy, and Manufacturing Engineering Development 2017 and IBSAP (Indonesian Biodiversity Strategy and Action Plan) project 2018-2019.

\section{References}

1. Jin, X. C., Liu, G. Q., Xu, Z. H. \& Tao, W. Y., Decolorization of a dye industry effluent by Aspergillus fumigatus XC6. Appl. Microbiol. Biotechnol., 74(1): 239-243 (2007).

2. Rani, B., Kumar, V., Singh, J., Bisht, S., Teotia, P., Sharma, S. \& Kela, R., Bioremediation of dyes by fungi isolated from contaminated dye effluent sites for bio-usability. Brazilian J. Microbiol., 45(3): 1055-1063 (2014).

3. Ellouze, M. \& Sayadi, S., White-rot fungi and their enzymes as a biotechnological tool for xenobiotic bioremediation. in Management of Hazardous Wastes, (eds. Saleh, H. E.-D. M. \& Rahman, R. O. A.), IntechOpen, 103-120 (2016).

4. Wesenberg, D., Kyriakides, I. \& Agathos, S. N., White-rot fungi and their enzymes for the treatment of industrial dye effluents. Biotechnol. Adv., 22(1-2): 161-187 (2003).

5. Jebapriya, G. R. \& Gnanadoss, J. J., Bioremediation of textile dye using whiterot fungi: a review. Int. J. Curr. Res. Rev., 5(3): 1-13 (2013). 
6. Andleeb, S., Atiq, N., Ali, M. I., Ur-Rehman, F., Hameed, A. \& Ahmad, S., Biodegradation of anthraquinone dye by Aspergillus niger SA1 in self designed fluidized bed bioreactor. Iran. J. Environ. Heal. Sci. Eng., 7(5): 371-376 (2010).

7. Morales-Álvarez, E. D., Rivera-Hoyos, C. M., González-Ogliastri, N., RodríguezVázquez, R., Poutou-Piñales, R. A., Daza, C. E. \& Pedroza Rodriguez, A. M., Partial removal and detoxification of Malachite Green and Crystal Violet from laboratory artificially contaminated water by Pleurotus ostreatus. Univ. Sci., 21(3): 259285 (2016).

8. Falah, S., Sari, N. M. \& Hidayat, A., Decolorization of remazol Brilliant blue $\mathrm{R}$ by laccase of newly isolated Leiotrametes flavida strain ZUL62 from Bangka heath forest, Indonesia. Biodiversitas, 19(2): 583589 (2018).

9. Banat, I. M., Nigam, P., Singh, D. \& Marchant, R., Microbial decolourization of textile-dye-containing effluents: a review. Bioresour. Technol., 58(3): 217-227 (1996).

10. Asgher, M., Azim, N. \& Bhatti, H. N., Decolorization of practical textile industry effluents by white rot fungus Coriolus versicolor IBL-04. Biochem. Eng. J., 47(1-3): 61-65 (2009).

11. Parmar, N. D. \& Shukla, S. R., Decolourization of dye wastewater by microbial methods-A review. Indian J. Chem. Technol., 25(4): 315-323 (2019).

12. Wahyudi, T. R., Rahayu, S. \& Azwin, A., Keanekaragaman jamur Basidiomycota di hutan tropis dataran rendah Sumatera, Indonesia (studi kasus di Arboretum Fakultas Kehutanan Universitas Lancang Kuning Pekanbaru). Wahana For. J. Kehutan., 11(2): 98-111 (2016).

13. Naidu, B., Reddy, R., Satyanarayana, R. K. \& Prakasam, V., A study of synthetic lignin decolorization ability of P. chrysosporium, T. hirsuta and marine fungi. African $J$. Environ. Econ. Manag., 2(4): 195-197 (2014).

14. Ratanapongleka, K. \& Phetsom, J., Decolorization of synthetic dyes by crude lacasse from Lentinus polychrous Lev. Int. J. Chem. Eng. Appl., 5(1): 26-30 (2014).

15. Yanto, D. H. Y., Tachibana, S. \& Itoh, K., Biodecolorization of textile dyes by immobilezed enzymes in a vertical bioreactor system. Procedia Environ. Sci., 20: 235-244 (2014).

16. Anita, S. H., Sari, F. P., Oktaviani, M., Laksana, R. P. B. \& Yanto, D. H. Y., Biodekolorisasi pewarna tekstil antrakuinon menggunakan isolat jamur tropis Indonesia. in Prosiding Seminar Lignoselulosa, 129: 148-154 (2018).

17. Anita, S. H., Ardiati, F. C., Oktaviani, M., Sari, F. P., Nurhayat, O. D., Ramadhan, K. P. \& Yanto, D. H. Y., Immobilization of laccase from Trametes hirsuta EDN 082 in light expanded clay aggregate for decolorization of Remazol Brilliant Blue $\mathrm{R}$ dye. Bioresour. Technol. Reports, 12: 100602 (2020).

18. Oktaviani, M. \& Yanto, D. H. Y., Biodecolorization of textile dye by isolated tropical fungi. in Proceedings of International Conference of Indonesia Forestry Researchers III-2015, 276-285 Institut Pertanian Bogor, (2016).

19. Seshikala, D. \& Charya, M. A. S., Collection and screening of Basidiomycetes for better lignin degraders. Int. J. Life Sci. Biotechnol. Pharma Res., 4(1): 203-211 (2012).

20. Sharma, A., Aggarwal, N. K. \& Yadav, A., Isolation and screening of lignolytic fungi from various ecological niches. Univers. J. Microbiol. Res., 5(2): 25-34 (2017).

21. Risdianto, H., Sofianti, E., Suhardi, S. H. \& Setiadi, T., Optimisation of laccase production using white rot fungi and agriculture wastes in solid state fermentation. ITB J. Eng. Sci., 44(2): 93-105 (2012).

22. Vrsanska, M., Voberkova, S., Langer, V., Palovcikova, D., Moulick, A., Adam, V. \& Kopel, P., Induction of laccase, lignin peroxidase and manganese peroxidase activities in white-rot fungi using copper complexes. Molecules, 21(11): 1553 (2016). 
23. Afreen, S., Anwer, R., Singh, R. K. \& Fatma, T., Extracellular laccase production and its optimization from Arthrospira maxima catalyzed decolorization of synthetic dyes. Saudi J. Biol. Sci., 25(7): 1446-1453 (2018).

24. Patel, H., Gupte, S., Gahlout, M. \& Gupte, A., Purification and characterization of an extracellular laccase from solid-state culture of Pleurotus ostreatus HP-1. 3 Biotech, 4(1): 77-84 (2014).

25. Dao, A. T. N., Vonck, J., Janssens, T. K. S., Dang, H. T. C., Brouwer, A. \& de Boer, T. E.,
Screening white-rot fungi for bioremediation potential of 2,3,7,8tetrachlorodibenzo-p-dioxin. Ind. Crops Prod., 128: 153-161 (2019).

26. Plácido, J., Chanagá, X., Ortiz-Monsalve, S., Yepes, M. \& Mora, A., Degradation and detoxification of synthetic dyes and textile industry effluents by newly isolated Leptosphaerulina sp. from Colombia. Bioresour. Bioprocess., 3(1): 1-14 (2016). 